\title{
Response of Pole Beans (Phaseolus vulgaris L.) to Various Plant Densities'
}

\author{
Gerardo Mangual Crespo and Carlos J. Torres ${ }^{2}$
}

\begin{abstract}
The effect of four spacings within the row $(8,15,23$ and $30 \mathrm{~cm})$ on the marketable yield of four commercial pole bean varieties, (McCaslan 42, Romano, Kentucky 191 and Blue Lake S-7 Stringless), was evaluated on a winter planting at the Adjuntas Experiment Substation.

At the $8 \mathrm{~cm}$ spacing, variety Romano was the highest yielder $(12,523$ $\mathrm{kg} / \mathrm{ha}$ ) while Kentucky 191 had the lowest $(9,542 \mathrm{~kg} / \mathrm{ha})$. At $15 \mathrm{~cm}$, Kentucky 191 yielded $10,004 \mathrm{~kg} / \mathrm{ha}$; and McCaslan 42 only $8,297 \mathrm{~kg} / \mathrm{ha}$. At $23 \mathrm{~cm}$, Blue Lake S-7 was highest in yield $(11,587 \mathrm{~kg} / \mathrm{ha})$ while Romano had the lowest $(5,928 \mathrm{~kg} / \mathrm{ha})$. At $30 \mathrm{~cm}$, Kentucky 191 was the highest yielder $(9,442$ $\mathrm{kg} / \mathrm{ha}$ ) while McCaslan 42 was the lowest $(4,659 \mathrm{~kg} / \mathrm{ha})$.
\end{abstract}

\section{INTRODUCTION}

Low plant populations per unit area are probably among the main factors conducive to low yields of various crops $(3,4,5,6,7,9)$.

Pole bean production in the United States has been declining during the past years mainly because harvesting is done manually and labor costs are exceedingly high. Very specific areas like Dade County in Florida (1) planted 3,600 acres of pole beans in 1972. In Puerto Rico, pole bean production on a commercial basis is almost nil; and the current demand for this crop is very low although some pole beans of good quality might be marketed if proper promotion could be given.

The purpose of the study herein reported was to determine the best row spacing for four pole bean varieties in west-central Puerto Rico.

\section{MATERIALS AND METHODS}

A pole bean planting was established on December 20, 1977 at the Agricultural Experiment Substation farm, Adjuntas, at 675 meters above sea level on a Humatas soil, Typic Tropohumults, clayey, kaolinitic, isohyperthermic. A split plot design was used with four replications of commercial varieties McCaslan 42, Romano, Kentucky 191 and Blue Lake S-7 Stringless.

The main plots were assigned to row distances and the subplots to varieties. Plant densities corresponded to $8,15,23$ and $30 \mathrm{~cm}$ between plants in the row, with $90 \mathrm{~cm}$ between rows, equivalent to theoretical densities of $141,116,70,558,47,039$ and 35,279 plants/ha. Seed was sown by hand in rows $6 \mathrm{~m}$ long.

${ }^{1}$ Manuscript submitted to Editorial Board November 21, 1978.

${ }^{2}$ Assistant Agronomists, Agricuitural Experiment Station, Mayagüez Campus, University of Puerto Rico, Río Piedras, P.R. 
Poles two meters long were spaced 6.1 meters apart along each row. Wire no. 12 was nailed at $60 \mathrm{~cm}$ intervals from the ground up. A piece of string was tied to each plant as soon as it was approximately $30 \mathrm{~cm}$ tall and was guided to the wire for support.

Dacthal $75 \mathrm{~W}^{3}$ was applied as a preemergent herbicide immediately after planting at the rate of $11.25 \mathrm{~kg}$ of the active ingredient/ha. Overhead irrigation was applied twice during the first week and once a week afterwards, until flowering. Also furrow irrigation was used as necessary. A weekly spraying program was followed, mixing Diazinon AG500 and Dithane M-45 at the rate of $1200 \mathrm{ml}$ and $2.25 \mathrm{~kg} / \mathrm{ha}$, respectively, to reduce damage by insects and diseases.

An evaluation as to rust susceptibility was made during the growing cycle, classifying the varieties as follows: Susceptible, slightly susceptible or highly susceptible.

TABLE 1.-Marketable yields of four pole-bean varieties at various spacings at Adjuntas, 1977

\begin{tabular}{lrrrr}
\hline \multirow{2}{*}{ Varieties } & \multicolumn{4}{c}{ Yields within the indicated row spacings $(\mathrm{cm})$} \\
\cline { 2 - 5 } & 8 & 15 & 23 & 30 \\
\hline & & \multicolumn{3}{c}{$T / h \mathrm{a}$} \\
McCaslan 42 & $11.1 \mathrm{a}^{1}$ & $9.1 \mathrm{a}$ & $9.2 \mathrm{a}$ & $5.1 \mathrm{~b}$ \\
Romano & $13.8 \mathrm{a}$ & $9.2 \mathrm{~b}$ & $6.5 \mathrm{~b}$ & $5.9 \mathrm{~b}$ \\
Kentucky 191 & $10.5 \mathrm{a}$ & $11.0 \mathrm{a}$ & $10.0 \mathrm{a}$ & $10.4 \mathrm{a}$ \\
Blue Lake S-7 Stringless & $10.9 \mathrm{a}$ & $10.0 \mathrm{a}$ & $12.7 \mathrm{a}$ & $6.9 \mathrm{~b}$ \\
\hline
\end{tabular}

${ }^{1}$ Means in a row with one or more letters in common do not differ significantly at the $5 \%$ probability level.

Harvesting was done at weekly intervals beginning 58 days after planting for Kentucky 191 and 63 days after planting for McCaslan 42, Romano and Blue Lake S-7 Stringless.

\section{RESULTS AND DISCUSSIONS}

Table 1 and figure 1 show the marketable yields of the four varieties. The tendency was for higher yields as plant density increased. This has also been reported, among others, by Mangual $(4,5)$ with snap beans and by González Ríos and Riollano (2) with field beans.

Yields in this trial were much higher than those obtained by Ramírez and Vélez (8) who studied two of the varieties herein included. This is more probably due to the closer spacings utilized in this case in contrast with those used by Ramírez and Vélez.

${ }^{3}$ Trade names in this publication are used only to provide specific information. Mention of a trade name does not constitute a warranty of equipment or materials by the Agricultural Experiment Station of the University of Puerto Rico, nor is this mention a statement of preference over other equipment or materials. 

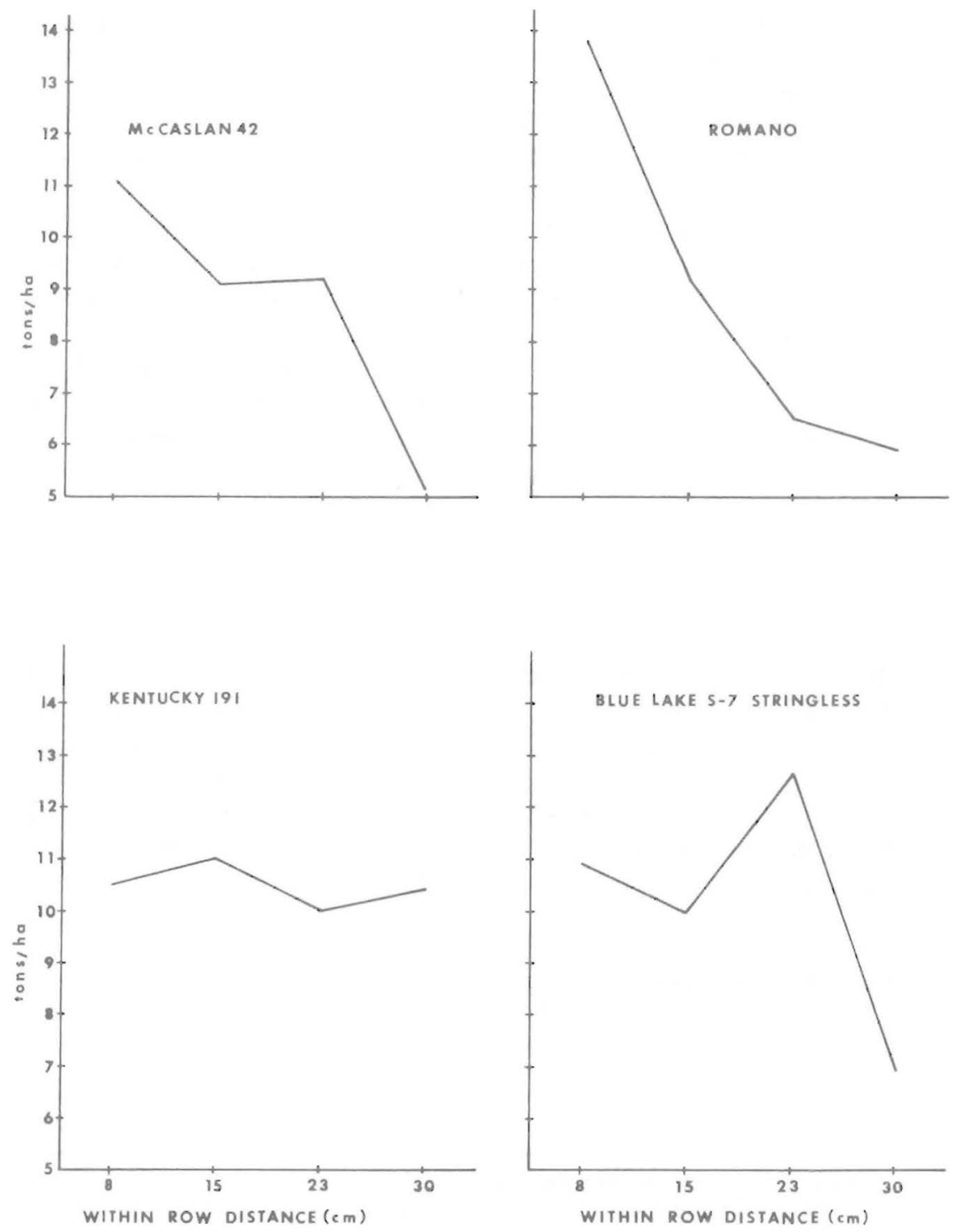

FIG. 1.-Pole bean yields at various plant densities.

At wider spacings, Ramírez and Vélez obtained 6.2 tons/ha with their lowest yielder. However, in all of the spacings Kentucky 191 almost doubled this amount.

There were no significant differences between varieties, but yield differences attributable to spacing were significant.

The highest yield was scored by Romano at the $8 \mathrm{~cm}$ spacing, being 
significantly different from those of the same variety at wider spacings. Yields at the $8 \mathrm{~cm}$ spacing were statistically superior to yields from the $30 \mathrm{~cm}$ spacings in all varieties, except Kentucky 191.

Irrespective of variety, the tendency was for higher yields from the 8 $\mathrm{cm}$ spacing with a mean of $11.6 \mathrm{t} / \mathrm{ha}$ as against the lowest in the $30 \mathrm{~cm}$ spacing, with a mean of $7.01 \mathrm{t} / \mathrm{ha}$.

Varieties Kentucky 191 and McCaslan 42 were highly susceptible to rust, Uromyces phaseoli, a characteristic which disqualified these varieties for commercial use. Blue Lake S-7 is susceptible while Romano is slightly susceptible.

Mean pod length was 19, 18 and $14 \mathrm{~cm}$ for McCaslan 42, Kentucky 191 and Blue Lake S-7, respectively, while Romano averaged $11 \mathrm{~cm}$. Romano's pod is not as eye-appealing as those of the other varieties.

\section{RESUMEN}

En la Subestación Experimental Agrícola de Adjuntas se estableció una siembra con cuatro variedades comerciales de habichuelas trepadoras con el propósito de determinar el efecto de cuatro distancias entre plantas en la hilera sobre el rendimiento.

A $8 \mathrm{~cm}$ entre plantas la variedad Romano produjo rendimiento máximo $(12,523 \mathrm{~kg} / \mathrm{ha})$, mientras que Kentucky 191 produjo el mínimo $(9,542$ $\mathrm{kg} / \mathrm{ha}$ ). A $15 \mathrm{~cm}$ Kentucky 191 registró 10,004 kg/ha mientras que McCaslan 42 solo dio 8,297 kg/ha. A $23 \mathrm{~cm}$, Blue Lake S-7 fue la de rendimiento máximo $(11,587 \mathrm{~kg} / \mathrm{ha})$ y Romano el mínimo $(5,928 \mathrm{~kg} / \mathrm{ha})$. A $30 \mathrm{~cm}$, Kentucky 191 produjo el rendimiento máximo $(9,442 \mathrm{~kg} / \mathrm{ha})$ y McCaslan 42 el mínimo $(4,659 \mathrm{~kg} / \mathrm{ha})$.

\section{LITERATURE CITED}

1. Fla. Cooperative Extension Service, Institute of Food and Agri. Sci. Bean (Bush and Pole) Production Guide. Cir. 100 C. Univ. Fla. Gainesville, Fla.

2. González-Ríos, P. and Riollano, A., 1951. El mejoramiento de la habichuela blanca del país por medio de la selección, Esta. Exp. Univ. P.R. Agri. Bol. 94.

3. Goulden, D. S., 1976. Effect of plant population and row spacing on yield and components of yield of navy beans (Phaseolus vulgaris). N.Z., J. Exp. Agri. 4: 77-180.

4. Mangual-Crespo, G. and Torres, C. J., 1978. Response of snap beans (Phaseolus vulgaris) to increasing plant density, Agri. Univ. P.R. 63 (3).

5. — Orengo, E., and Ramírez, C. T., 1979. Effect of plant spacing and fertilizer levels on yield and dry bulb weight of onion cv. Texas Grano 502, J. Agri. Univ. P.R. 63 (4).

6. Ortega, S. and Barrios, A., 1968. Sistema de siembra en hileras pares en caraota, Agron. Trop. 18 (3): 357-61.

7. Palevith, Dan., 1970. Effects of plant population and pattern on yield of broccoli (Brassica oleracea var. italica) in single harvest. Hort. Sci. 5 (4).

8. Ramírez, O. D. and Vélez-Santiago, J., 1962. Snap bean variety trials in east-central Puerto Rico. J. Agri. Univ. P.R. 46 (3): 213-18.

9. Sánchez-Nieva, F., 1977. Evaluación de algunas variedades de habichuelas tiernas para elaboración, Esta. Exp. Agri. Univ. P.R. Bol. 257. 